\title{
Financial Performance Measurement using Solvency Ratio at PT. AKR Corporindo Tbk. 2015-2019 Period
}

\author{
Bella Puspita Rininda, Yuli Fitriyani, Azizah
}

\begin{abstract}
This study aims to measure the financial performance of PT AKR Corporindo Tbk's 2015-2019 financial statements by using the solvency ratio. The method in this research is quantitative. The subject in this study is the financial statements of PT AKR Corporindo Tbk in 2015-2019 using the solvency ratio. The results of this study indicate that the assessment of financial performance at PT. AKR Corporindo Tbk, for the debt to asset ratio is considered not good because it exceeds the industry average standard that has been set, the debt to equity ratio is considered healthy even though it exceeds the industry average standard, because large funds are obtained from short-term debt, namely debt business, and the long term debt to equity ratio is also considered good because it is below the industry average standard. The results of this study indicate that the solvency ratio at PT AKR Corporindo Tbk has decreased and increased according to industry standards.
\end{abstract}

Keywords: Financial Statements, Financial Performance, Solvency Ratio.

\section{INTRODUCTION}

$\mathrm{E}$ ra of globalization, many companies are engaged in the supply of services to assist the operation of production activities. The company itself is a place where production activities occur and the gathering of all factors of production. Providing quality services is closely related to resource management, namely financial management, human resources, and the provision of complete facilities and infrastructure.

Economic developments in the current era make more interested parties think more creatively in following the development of financial information. The important thing and needs to be known in the development of a company is the financial element because the financial element is used to determine a policy taken whether it is appropriate or not, given how much influence the emergence of problems that can cause bankruptcy due to financial factors that do not work correctly. The company is the one that provides information about the finances, namely the financial statements used by the company concerned to report its financial condition to parties in need, which are primarily for investors, creditors, and the company's management. The company must be more transparent and complete in presenting its financial statements.

The company was founded as a valuable organizational place to meet human needs, and the goal is to get maximum profit. For this goal to be achieved, the company must have good management in making its financial statements. The company's financial condition can be balanced if it can finance the activities carried out and do not experience difficulties fulfilling its obligations to other parties, both short and long term. In this case, the company's financial management role is needed to plan precisely how to fulfill, use, and supervise the allocation of funds.

Financial statements are prepared based on financial data presented in financial statements such as consolidated statements of financial position, consolidated statements of changes in equity, income statements, and cash flow statements. Financial statements can also reflect the company's weaknesses and strengths in a certain period and can find out the company's financial condition. Financial reports made can be used by internal and external parties.

Internal parties need information from the results of financial statement analysis to assist them in managing, planning, and controlling company activities, which includes internal parties, namely company leaders, managers, and employees. Meanwhile, external parties such as investors, creditors, the government, and the public are used to determine whether investors can provide loans or credit to the company. Financial statement analysis is a process that is full of judgment to help evaluate the current and past financial position and results of operations of the company, which aims to determine the most likely elimination and prediction regarding the condition and performance of the company in the future.

PT. AKR Corporindo Tbk. is a multinational company that provides integrated supply chain solutions services. This company is the largest private company in Indonesia which is engaged in trading and distributing fuel and basic chemicals. The company is also engaged in logistics services and the manufacturing of sorbitol and adhesives. The company also operates in coal mining, infrastructure, and manufacturing through several subsidiaries. PT. AKR Corporindo Tbk. Released the unsatisfactory first semester 2019 financial report. Thus, this decline in performance was reflected in its shares slumping in trading up to 90 points or minus $2.20 \%$ to the level of Rp. 4,000 per share (Rahayu, 2019).

Companies need to analyze their financial statements because financial statements are used to measure company performance. Financial performance is an analytical process that is carried out to see a company's good and bad financial conditions in a certain period. The tool used to measure financial performance is ratio analysis. Analysis of the financial ratios of a company is critical for potential investors to determine how much investment they can provide. The 
results of this analysis can be used as a reference for business development (Utami, 2020).

Based on the above explanation, the authors are interested in measuring the financial performance of the financial statements of PT. AKR Corporindo Tbk. for 2015-2019 by using the solvency ratio or leverage ratio used to show the number of assets funded by debt.

\section{ReSEARCH METHOD}

In this study, the author uses quantitative data types, namely data presented in numbers. This type of data aims to provide an overview of specific characteristics by using statistical tests that will answer the research problem.

The source of the data obtained is secondary data, calculated data, or data in the form of numbers; in this case, the data taken is the Financial Report of PT. AKR Corporindo Tbk. 2015-2019 which researchers got from the Indonesia Stock Exchange (IDX) website on the Idx site.

The technique used by the author in this research is Literature and Studies Documentation. Literature study is a data collection technique by looking for references related to the problem to be studied by the author as the library's purpose. Literature studies are obtained from books, journals, articles, or the web related to the problem studied. The documentation is data obtained from the official website of the Indonesia Stock Exchange (IDX) on the IDX data site published from 2015 to 2019. The analytical tools used by the author are Debt to Asset Ratio, Debt to Equity Ratio, and Long Term Debt to Equity.

\section{Results ANd Discussion}

\subsection{Result}

The analytical tools used by the author are Debt to Asset Ratio, Debt to Equity Ratio, and Long Term Debt to Equity Ratio using simplified financial statement data as below:

Table 1. Data PT. AKR Corporindo Tbk.

\begin{tabular}{|c|c|c|c|c|}
\hline $\begin{array}{c}\text { Yea } \\
\mathbf{r}\end{array}$ & $\begin{array}{c}\text { Total } \\
\text { Assets } \\
\text { (Rp) }\end{array}$ & $\begin{array}{l}\text { Total Debt } \\
\quad(\mathbf{R p})\end{array}$ & $\begin{array}{l}\text { Total } \\
\text { Equity } \\
\text { (Rp) }\end{array}$ & $\begin{array}{l}\text { Long- } \\
\text { Term Debt } \\
\text { (Rp) }\end{array}$ \\
\hline $\begin{array}{c}201 \\
5\end{array}$ & $\begin{array}{c}15,203,129.5 \\
63\end{array}$ & $\begin{array}{c}7,916,954,22 \\
0\end{array}$ & $\begin{array}{c}7,286,175,34 \\
3\end{array}$ & $\begin{array}{c}3,045,552,0 \\
87\end{array}$ \\
\hline $\begin{array}{c}201 \\
6\end{array}$ & $\begin{array}{c}15,830,740,7 \\
10\end{array}$ & $\begin{array}{c}7,756,420,38 \\
9\end{array}$ & $\begin{array}{c}8,074,320,32 \\
1\end{array}$ & $\begin{array}{c}1,940,712,8 \\
63\end{array}$ \\
\hline $\begin{array}{c}201 \\
7\end{array}$ & $\begin{array}{c}16,823 \\
.208,531\end{array}$ & $\begin{array}{c}7,793,559,18 \\
4\end{array}$ & $\begin{array}{c}9,029,649,34 \\
7\end{array}$ & $\begin{array}{c}2,364,067,7 \\
27\end{array}$ \\
\hline $\begin{array}{c}201 \\
8\end{array}$ & $\begin{array}{c}19,940,850,5 \\
99\end{array}$ & $\begin{array}{c}10,014,019,2 \\
60\end{array}$ & $\begin{array}{c}9,926,831,33 \\
9\end{array}$ & $\begin{array}{c}1,951,291,4 \\
36\end{array}$ \\
\hline $\begin{array}{c}201 \\
9\end{array}$ & $\begin{array}{c}21,409,046,1 \\
73\end{array}$ & $\begin{array}{c}11,342,184,8 \\
33\end{array}$ & $\begin{array}{c}10,066,861,3 \\
40\end{array}$ & $\begin{array}{c}2,629,658,6 \\
02\end{array}$ \\
\hline
\end{tabular}

Source: Data processed based on financial reports AKR Corporindo Tbk. Year 2020
The following is the calculation of the Debt Expense Report borne by PT. AKR Corporindo Tbk. 2015-2019:

Table 2. Debt Data of PT. AKR Corporindo Tbk.

\begin{tabular}{|c|c|c|c|}
\hline Year & Total Debt (Rp) & $\begin{array}{c}\text { Increase/Decrease } \\
(\mathrm{Rp})\end{array}$ & $\%$ \\
\hline 2015 & $7,916,954,220$ & & \\
\hline 2016 & $7,756,420,389$ & $(160,533,831)$ & $(2.0)$ \\
\hline 2017 & $7,793,559,184$ & $37,138,795$ & 0.5 \\
\hline 2018 & $10,014,019,260$ & $2,220,460,076$ & 28,5 \\
\hline 2019 & $11,342,184,833$ & $1,328,165,573$ & 13.3 \\
\hline
\end{tabular}

Source: The data is processed based on the financial statements of PT. AKR Corporindo Tbk. In 2020

From the data above, it can be concluded that the total debt burden for 2015 was Rp. 7,916,954,220 and in 2016 it was Rp. $7,756,420,389$ which decreased by Rp. 160,533,831 equivalent to $2.0 \%$. Debt expenses in 2016 amounted to Rp 7,756,420,389 and in 2017 amounted to $\operatorname{Rp} 7,793,559,184$ which increased by Rp 37,138,795 equivalent to 0.5\%. Debt expense in 2017 was IDR 7,793,559,184 and in 2018 it was IDR 10,014,019,260 which increased by IDR 2,220,460,076 equivalent to $28.5 \%$. Debt expense in 2018 was Rp. 10,014,019,260, while in 2019 it was Rp. 11,342,184,833 which increased by Rp. 1,328,165,573 equivalent to $13.3 \%$. When compared to 2018 , the company's debt burden decreased by Rp. 892,294,503 which equivalent to $11.4 \%$.

The following is a calculation of the ability of PT. AKR Corporindo Tbk. in paying debts to assets and equity:

1. Debt to Asset Ratio

Table 3. Debt to Asset Ratio (in a million Rupiah)

\begin{tabular}{||c|c|c|c|c|}
\hline Year & $\begin{array}{c}\text { Total Assets } \\
\text { (a) (Rp) }\end{array}$ & $\begin{array}{c}\text { Total Debt (b) } \\
\text { (Rp) }\end{array}$ & $\begin{array}{c}\text { Debt to } \\
\text { Asset } \\
\text { Ratio (c) } \\
\text { = b: a } \\
\text { (Rp) }\end{array}$ & $\begin{array}{c}\text { Debt to } \\
\text { Asset } \\
\text { Ratio } \\
\%\end{array}$ \\
\hline 2015 & $15,203,129.563$ & $7,916,954,220$ & 0.52 & 52 \\
\hline 2016 & $15,830,740,710$ & $7,756,420,389$ & 0.49 & 49 \\
\hline 2017 & $16,823,208,531$ & $7,793,559,184$ & 0,46 & 46 \\
\hline 2018 & $19,940,850,599$ & $10,014,019,260$ & 0.50 & 50 \\
\hline 2019 & $21,409,046,173$ & $11,342,184,833$ & 0.53 & 53 \\
\hline
\end{tabular}

Source: Data processed based on the financial statements of PT. AKR Corporindo Tbk. In 2020

Based on these calculations addressed that by 2015 the debt to asset ratio of $52 \%$, which means that every USD 1,00 the company's assets are financed by debt of 0.52 , and the remaining 0.48 or $48 \%$ is financed by the company. In 2016 
there was a decrease of $049 \%$, meaning that every Rp. 1.00 of the company's assets was financed by debt by 0.49 , and the company financed the remaining 0.51 or $51 \%$. In 2017 it decreased by $46 \%$, meaning that for every IDR 1.00 the company's assets were financed by debt by 0.46 , and the remaining 0.54 or $56 \%$ was financed by the company. In 2018 there was an increase in funding financed by debt by $50 \%$, meaning that if every IDR 1.00 of company assets were financed by debt by 0.50 and the remaining 0.50 or $50 \%$ was financed by the company. In 2019 there was another increase for funding financed by debt to $53 \%$, meaning that for every IDR 1.00 the company's assets were financed by debt by 0.53 , and the remaining 0.47 or $47 \%$ was financed by the company.

\section{Debt to Equity Ratio}

Table 4. Debt to Equity Ratio (in a million Rupiah)

\begin{tabular}{|c|c|c|c|c|}
\hline Year & $\begin{array}{c}\text { Total Equity } \\
\text { (a) (Rp) }\end{array}$ & $\begin{array}{c}\text { Total Debt (b) } \\
(\mathrm{Rp})\end{array}$ & $\begin{array}{c}\text { Debt to } \\
\text { Equity } \\
\text { Ratio (c) } \\
\text { (b: a } \\
\text { (Rp) }\end{array}$ & $\begin{array}{c}\text { Debt to } \\
\text { Equity } \\
\text { Ratio } \\
\%\end{array}$ \\
\hline 2015 & $7,286,175,343$ & $7,916,954,220$ & 1.09 & 109 \\
\hline 2016 & $8,074,320,321$ & $7,756,420,389$ & 0.96 & 96 \\
\hline 2017 & $9,029,649,347$ & $7,793,559,184$ & 0.86 & 86 \\
\hline 2018 & $9,926,831.339$ & $10,014,019,260$ & 1,01 & 101 \\
\hline 2019 & $10,066,861,340$ & $11,342,184,833$ & 1.13 & 113 \\
\hline
\end{tabular}

Source: Data processed based on the financial statements of PT. AKR Corporindo Tbk. In 2020

Based on these calculations, it shows that in 2015 the debt to equity ratio was $109 \%$, which means Rp. 100.00 provided by shareholders, $109 \%$ of the company's funding is provided by creditors. In 2016 there was a decrease in corporate funding by creditors by $96 \%$, which means Rp. 100.00 provided by shareholders and $96 \%$ of corporate funding provided by creditors. In 2017 there was another decline in corporate funding by creditors by $86 \%$, which means that Rp. 100.00 provided by shareholders was $86 \%$ of corporate funding provided by creditors. In 2018 corporate funding by creditors increased to $101 \%$, meaning that Rp. 100.00 provided by shareholders was $101 \%$ of corporate funding provided by creditors. In 2019 there was another increase in corporate funding by creditors by $113 \%$, meaning that Rp. 100.00 provided by shareholders was $113 \%$ of corporate funding provided by creditors.

3. Long Term Debt to Equity Ratio

Table 5. Long Term Debt to Equity Ratio (in a million Rupiah)

\begin{tabular}{|c|c|c|c|}
\hline Year & $\begin{array}{c}\text { Total Equity (a) } \\
(\mathrm{Rp})\end{array}$ & $\begin{array}{c}\text { Total Debt } \\
\text { Long Term (b) }\end{array}$ & $\begin{array}{c}\text { Long Term } \\
\text { Debt to }\end{array}$ \\
\hline
\end{tabular}

\begin{tabular}{|c|c|c|c|}
\hline & & $(\mathrm{Rp})$ & $\begin{array}{c}\text { Equity Ratio } \\
(\mathrm{c})=\mathrm{b}: \mathrm{a} \\
(\mathrm{Rp})\end{array}$ \\
\hline 2015 & $7,286,175,343$ & $3,045,552,087$ & 0.42 \\
\hline 2016 & $8,074,320,321$ & $1,940,712,863$ & 0.24 \\
\hline 2017 & $9,029,649,347$ & $2,364,067,727$ & 0.26 \\
\hline 2018 & $9,926,831,339$ & $1,951,291,436$ & 0.20 \\
\hline 2019 & $10,066,861,340$ & $2,629,658,602$ & 0.26 \\
\hline
\end{tabular}

Source: Data processed based on the financial statements of PT. AKR Corporindo Tbk. In 2020

Based on these calculations, it shows that PT. AKR Corporindo Tbk. pledged every IDR 0.42 of his capital to make long-term company loans in 2015. In 2016 his collateral decreased by IDR 0.24 of his capital to make long-term company loans. In 2017 the guarantee was an increase of Rp. 0.26 from the capital it has to make long-term company loans. In 2018 the guarantee decreased by Rp. 0.20 from the capital it has to make long-term company loans. In 2019 the guarantee increased by Rp. 0.26 from the capital it has to make long-term company loans.

\subsection{Discussion}

1. Debt to Asset Ratio

Table 1. Industry Standard Debt to Asset Ratio

\begin{tabular}{ccccccc}
\hline $\begin{array}{c}\text { Solvency } \\
\text { Ratio }\end{array}$ & $\begin{array}{c}\text { Industry } \\
\text { Standard }\end{array}$ & $\mathbf{2 0 1 5}$ & $\mathbf{2 0 1 6}$ & $\mathbf{2 0 1 7}$ & $\mathbf{2 0 1 8}$ & $\mathbf{2 0 1 9}$ \\
\hline DAR & $\mathbf{3 5 \%}$ & $52 \%$ & $49 \%$ & $46 \%$ & $50 \%$ & $53 \%$ \\
\hline \multirow{2}{*}{ Description } & \multirow{2}{*}{ Good } & Not & Not & Not & Not & Not \\
& & Good & Good & Good & Good & Good \\
\hline
\end{tabular}

Sumber : Data diolah berdasarkan laporan keuangan PT. AKR Corporindo Tbk. Tahun 2020

Based on industry standards, the debt to asset ratio (DAR), according to Kasmir (2016), is 35\%, which means that when compared to the industry average standard, in 2015-2019, it has a debt to asset ratio that is above the industry standard, where every year it shows a decrease and increase, although it has decreased the figure is still above the industry average standard. This shows that its financial performance is considered poor because the company is financed with debt exceeding the industry average standard, meaning that its funding from debt is greater than the company itself. So, if this ratio is higher, the risk of the company will be greater if the company is liquidated; on the contrary, the smaller this ratio is, the better for the company in assessing its ability to fulfill its obligations. In this case, creditors tend to prefer companies with solvency ratios below the industry average to channel their loans. To maintain the level of debt to asset ratio, the company should be able to further increase its total assets to 
cover the company's debt.

2. Debt to Equity Ratio

Table 2. Industry Standard Debt to Equity Ratio

\begin{tabular}{ccccccc}
\hline \multirow{2}{*}{$\begin{array}{c}\text { Solvency } \\
\text { Ratio }\end{array}$} & $\begin{array}{c}\text { Industry } \\
\text { Standard }\end{array}$ & $\mathbf{2 0 1 5}$ & $\mathbf{2 0 1 6}$ & $\mathbf{2 0 1 7}$ & $\mathbf{2 0 1 8}$ & $\mathbf{2 0 1 9}$ \\
\hline DER & $\mathbf{9 0 \%}$ & $109 \%$ & $96 \%$ & $86 \%$ & $101 \%$ & $113 \%$ \\
\hline \multirow{2}{*}{ Description } & Good & Good & Good & Good & Good & Good \\
\cline { 3 - 6 } & & \multicolumn{3}{c}{ Based on Long-Term Liabilities } \\
& & Comparison and Short-Term Liabilities \\
\hline
\end{tabular}

Source: The data is processed based on the financial statements of PT. AKR Corporindo Tbk. In 2020

According to Kasmir (2016), the industry standard for the debt to equity ratio (DER) is $90 \%$. Based on table 4.7 , it can be seen that in 2015 it exceeded the industry average standard; 2016-2017 was considered good because it was below the industry average standard. For 2018 and 2019, it is the same as 2015 exceeding the industry average standard because PT AKR Corporindo's debt has exceeded the ideal DER, which is below $100 \%$ or exceeding the industry average standard, considered flawed. So, the higher the ratio, the higher the company's risk level if the company is liquidated. However, the funds can be good for 2015, 2018, and 2019 because the short-term debt is more outstanding than the long-term debt. If the long-term debt is more significant than the short-term debt, the condition is unhealthy. Long-term debt is usually obtained from bank loans or bonds, while short-term debt is obtained from trade payables or debt due to upfront income. Therefore, to maintain the level of the DER ratio, the company must also increase its own capital so that the company can guarantee the company's debt and be trusted by creditors.

\section{Long Term Debt to Equity}

Table 3.

Industry Standard Long Term Debt to Equity

\begin{tabular}{ccccccc}
\hline $\begin{array}{c}\text { Solvency } \\
\text { Ratio }\end{array}$ & $\begin{array}{l}\text { Industry } \\
\text { Standard }\end{array}$ & $\mathbf{2 0 1 5}$ & $\mathbf{2 0 1 6}$ & $\mathbf{2 0 1 7}$ & $\mathbf{2 0 1 8}$ & $\mathbf{2 0 1 9}$ \\
\hline LTDER & 10 Times & 0,42 & 0,24 & 0,26 & 0,20 & 0,26 \\
\hline Description & Good & Good & Good & Good & Good & Good \\
\hline
\end{tabular}

Source: The data is processed based on the financial statements of PT. AKR Corporindo Tbk. In 2020

The industry standard for long term debt to equity (LTDER) according to Kasmir (2016) is 10 times. This means that for long term debt to equity at PT. AKRCorporindo Tbk, during 2015 to 2019 was considered good because the ratio results were below the industry average standard. This is very beneficial for creditors as providers of funds, because the smaller the long-term debt to equity ratio, the smaller the risk borne by the company for possible failures. The ability of PT evidences this. AKR Corporindo Tbk. is good at covering its long-term obligations by using its capital.

\section{Conclusion}

Based on the results of research carried out using the solvency ratio, the following conclusions can be drawnassessment of financial performance taken from the financial statements of PT. AKR Corporindo Tbk. by using the debt to asset ratio decreased and increased from 2015 to 2019, which exceeded the industry average standard. So, it can be concluded that the debt to asset ratio at PT. AKR Corporindo Tbk. 2015-2019 is considered less suitable, although it has decreased because it exceeds the industry average standardassessment of financial performance taken from the financial statements of PT. AKR Corporindo Tbk. by using the debt to equity ratio, it has decreased and increased from 2015 to 2019. Based on this calculation, the debt to equity ratio is considered healthy even though it exceeds the industry average standard because significant funds are obtained from short-term debt, namely trade payables-assessment of financial performance taken from the financial statements of PT. AKR Corporindo Tbk. using long-term debt to equity is considered good because it is below the industry average standard, and it is very profitable for creditors as providers of funds.

PT AKR Corporindo Tbk is always expected to maintain the debt to asset ratio, debt to equity ratio, and long-term debt to equity to be below the industry average standards set. Because the smaller the solvency ratio, the better the financial performance by increasing funding from own capital. Thus the solvency ratio at PT. AKR Corporindo Tbk. can improve their financial performance and be able to use debt properly in order to repay.

\section{REFERENCES}

[1] Anastasya, Shinta, and Cholis Hidayati. 2019. “Analisis Rasio Keuangan Dan Common Size Untuk Menilai Kinerja Keuangan Perusahaan Kosmetik Dan Peralatan Rumah Tangga Yang Terdaftar Di Bursa Efek Indonesia Tahun 2013-2015." Jurnal Ekonomi Akuntansi 4(2):51-66.

[2] Beck, Thorsten, Asli Demirgüç-Kunt, and Ross Levine. 2007. "Finance, Inequality and the Poor." Journal of Economic Growth 12(1):27-49. doi: 10.1007/s10887-007-9010-6.

[3] Beck, Thorsten, Lemma Senbet, and Witness Simbanegavi. 2015. "Financial Inclusion and Innovation in Africa: An Overview." Journal of African Economies 24:i3-11. doi: 10.1093/jae/eju031.

[4] Bruhn, Miriam, and Inessa Love. 2014. "The Real Impact of Improved Access to Finance: Evidence from Mexico." Journal of Finance 69(3):1347-76. doi: 10.1111/jofi.12091.

[5] Fahmi, I. 2012. Analisis Laporan Keuangan. Bandung: Alfabeta.

[6] Harahap, Sofyan Syafri. 2010. Analisis Kritis Atas Laporan Keuangan. Jakarta: Raja Grafindo Persada.

[7] Harnanto. 2004. Analisis Laporan Keuangan. Yogyakarta: UPD AMP YKPN.

[8] Herawati, Helmi. 2019. "Pentingnya Laporan Keuangan Untuk Menilai Kinerja Keuangan Perusahaan." Jurnal Akuntansi Unihaz 2(1):16-25.

[9] Ikhsan, Nihayah Saefil, Ronny Malavia Mardani, and Budi Wahono. 2017. 
“Analisis Common Size Statement Dan Rasio Keuangan Untuk Meniai Kinerja Keuangan Sektor Industri Rokok Yang Tercatat Di BEI (Periode Tahun 2015-2017)." E - Jurnal Riset Manajemen 100-111.

[10] Iryani, Lia Dahlia, and Herlina Herlina. 2015. “Analisis Rasio Likuiditas, Solvabilitas, Dan Profitabilitas Dalam Mendukung Pembiayaan Pada Pt Bank Danamon Indonesia, Tbk." JIAFE (Jurnal Ilmiah Akuntansi Fakultas Ekonomi) 1(2):32-40. doi: 10.34204/jiafe.v1i2.514.

[11] Khanjaya, Cindy Yuliane, and Triyogo Moelyo Adi. 2016. “Analisis Laporan Keuangan PT Ciputra Property Tbk Sebagai Dasar Penilaian Kinerja Perusahaan Pada Periode 2011-2014." Jurnal Mahasiswa Bina Insani 1(1):2331.

[12] Levine, Ross, Norman Loayza, and Thorsten Beck. 2000. "Financial Intermediation and Growth: Causality and Causes without Outliers." Journal of Monetary Economics 46:31-77. doi: 10.1007/s10258-009-0035-y.

[13] Marimin, Agus, Abdul Haris Romdhoni, and Tira Nur Fitria. 2015. "Perkembangan Bank Syariah Di Indonesia." Jurnal Ilmiah Ekonomi Islam 1(2):75-87.

[14] Monok, Billy, Jhonny Montololu, and Henny S. Tarore. 2018. “Analisis Common Size Statement Pada PT. Asuransi Jiwasraya (Persero) Cabang Manado Kota." Jurnal Administrasi Bisnis 6(3):61-68. doi: 10.35797/jab.6.003.2018.20287.

[15] Prihadi, Toto. 2019. Analisis Laporan Keuangan: Konsep Dan Aplikasi. Jakarta: Gramedia Pustaka Utama.

[16] Rifardi, Riri, R. Deni Muhammad Danial, and Dicky Jhoansyah. 2019. "Analisis Kinerja Keuangan Dengan Menggunakan Metode Common Size Pada PT. Holcim Indonesia TBK." COSTING:Journal of Economic, Business and Accounting Volume 3(1):153-59.

[17] Runtuwene, Aditya, Frendy A. O. Pelleng, and Wilfried S. Manoppo. 2019. "Analisis Rasio Solvabilitas Untuk Mengukur Kinerja Keuangan Pada Bank SulutGo." Jurnal Administrasi Bisnis 9(2):9. doi: 10.35797/jab.9.2.2019.23896.918.

[18] Sari, Hana Febrina, and Adi Rahman. 2018. "Analisis Laporan Keuangan Untuk Menilai Kinerja Keuangan Pada PT. Kapuas Tata Steel Banjarbaru." Jurnal Ilmiah Ekonomi Bisnis 4(1):111-26.

[19] Shakil, Mohammad Hassan, Nihal Mahmood, Mashiyat Tasnia, and Ziaul Haque Munim. 2019. “Do Environmental, Social and Governance Performance Affect the Financial Performance of Banks? A Cross-Country Study of Emerging Market Banks." Management of Environmental Quality: An International Journal 30(6):1331-44. doi: 10.1108/MEQ-08-2018-0155.

[20] Shihadeh, Fadi Hassan, Azzam Mohammed Tayseer Hannon, Jian Guan, Ihtisham Ul Haq, and Xiuhua Wang. 2018. “Does Financial Inclusion Improve the Banks' Performance? Evidence from Jordan." Research in Finance 34:11738. doi: 10.1108/S0196-382120170000034005.

[21] Shintia, Novi. 2017. "Analisis Rasio Solvabilitas Untuk Menilai Kinerja Keuangan Terhadap Asset Dan Equity Pada PT Bank Rakyat Indonesia (PERSERO) Tbk Periode 2012-2015." At-Tadbir: Jurnal Ilmiah Manajemen $1(1): 41-63$.

[22] Sipahelut, Riana Christy, Sri Murni, and Paulina Van Rate. 2017. "Analisis Kinerja Keuangan Perusahaan (Studi Kasus Pada Perusahaan Sub Sektor Otomotif Dan Komponen Yang Terdaftar Di BEI Periode 2014-2016)." Jurnal EMBA: Jurnal Riset Ekonomi, Manajemen, Bisnis Dan Akuntansi 5(3):442534. doi: 10.35794/emba.v5i3.18641.

[23] Sugiono, A. 2009. Manajemen Keuangan. Jakarta: PT Gramedia Widiasarana Indonesia.

[24] Sulistias, Arut, and Farida Idayati. 2018. "Analisis Rasio Sebagai Tolak Ukur Kinerja Keuangan Pada PT. BPR Anekadana Sejahtera." Jurnal Ilmu Dan Riset Akuntansi 7(6).

[25] Syahidi, Fariz. 2017. “Analisis Kinerja Keuangan Pada Dinas Bina Marga Dan
Sumber Daya Air Kabupaten Banjar." Jurnal Ilmiah Ekonomi Bisnis 3(2):296300.

[26] Yulianti, Rahmah, Zainuddin, and Darmawan. 2019. “Analisis Kinerja Keuangan Pada PT Nippon Indosari Corpindo Tbk Yang Terdaftar Pada Bursa Efek Indonesia Periode 2012 - 2016." Journal of Economics Science 5(2):1-25. 